\title{
thWLF 2017 \\ Integration of Landslide Susceptibility Maps for Land Use Planning and Civil Protection Emergency Management
}

\author{
Sérgio C. Oliveira, José Luís Zêzere, Clémence Guillard-Gonçalves, \\ Ricardo A.C. Garcia, and Susana Pereira
}

\begin{abstract}
Landslides are one of the most relevant geomorphological hazards in Portugal, by the high levels of people affected, destruction of assets and disruption of economic and social activities. Regarding the Portuguese territorial land use planning and emergency management, regulation, practice, prevention and risk management have been promoted in different ways. In Portugal, the areas susceptible to landslides are included in the 'National Ecological Reserve', which is a public utility restriction legal figure that rules the land use planning at the municipal level. In addition, the Municipal Emergency Plans include landslide susceptibility maps that are combined with the map of the exposed elements, allowing the assessment of exposure to landslides. This study is applied to the Loures municipality located to the north of Lisbon. In this municipality 621 landslides registered in a landslide inventory (rotational slides, deep-seated translational slides and shallow translational slides) that affected $1,469,577 \mathrm{~m}^{2}(0.87 \%)$ of the Loures territory. The final landslide susceptibility map shows that in Loures municipality 1347 ha are associated to a Very high landslide susceptibility and 2372 ha to High landslide susceptibility, which corresponds both to $22.1 \%$ of the entire municipality, and constitutes the larger fraction of the National Ecological Reserve, related to landslides. These areas do not present geomorphological and geotechnical suitability for building structures or infrastructures. From the civil protection and emergency management point of views 34 classes of exposed elements were identified in the municipality, with point, linear and polygonal representations. The elements at risk located in the Very High or High landslide susceptibility classes were summarized and correspond to: high voltage poles; wind turbines; transmission/reception antennas; industrial areas; water tanks; silo; gas station/tank; service area; buildings of educational institutions; worship buildings; buildings of electricity facilities; regular buildings; gas pipeline; motorways; national roads; and municipal roads.
\end{abstract}

\section{Keywords}

Landslides • Susceptibility $・$ Land use planning $・$ Emergency management

S.C. Oliveira $(\bowtie) \cdot$ J.L. Zêzere · C. Guillard-Gonçalves

R.A.C. Garcia · S. Pereira

Institute of Geography and Spatial Planning, Universidade de

Lisboa, Edifício IGOT, Rua Branca Edmée Marques, Cidade

Universitária, 1600-276 Lisbon, Portugal

e-mail: cruzdeoliveira@campus.ul.pt

J.L. Zêzere

e-mail: zezere@ campus.ul.pt

\author{
C. Guillard-Gonçalves \\ e-mail: cguillard@campus.ul.pt \\ R.A.C. Garcia \\ e-mail:rgarcia@campus.ul.pt \\ S. Pereira \\ e-mail: susana-pereira@campus.ul.pt
}




\section{Introduction}

Landslides are one of the most relevant geomorphological hazards in Portugal, due the high levels of people affected, destruction of assets and disruption of economic and social activities. Regarding the Portuguese territorial land use planning and emergency management, regulation, practice, prevention and risk management have been recently promoted through different legal instruments.

In terms of the territorial planning since 2007 the National Program on Politics for the Territorial Planning assumes that preventive risk management is a priority vector for the spatial planning politics and a major conditioning factor within the Portuguese territorial model at all planning levels. Nevertheless, the land use regulation for both public institutions and private owners is only effective at the municipal scale. For landslide hazard the restrictions of land use have been safeguarded by the inclusion of areas susceptible to landslide occurrence in the public utility restriction legal figure named 'National Ecological Reserve' (NER), which includes the typology "Slope instability prone areas" (Decree-Law 166/2008 of August 22nd, changed and republished by the Decree-Law 239/2012, of November 2nd).

The NER integrates areas of ecological and sensitivity value and areas that require special protection due to excessive exposure and susceptibility to natural hazards. The NER establishes a set of constraints to the land occupation, use and transformation. In particular, along those areas classified as NER the following actions are forbidden: (a) housing development; (b) urbanization construction or expansion; (c) road construction; (d) excavation and embankment; and (e) destruction of vegetation cover, not including the necessary actions to the regular development of cultural operations of agricultural use and the exploitation of forest areas.

In Portugal the main objectives of the civil protection are the prevention and mitigation of collective risks and restoration of people's life routines following the occurrence of a severe accident or catastrophe. To accomplish these goals, rescue and assistance of people and other living beings are assumed as the priority action field of civil protection as well as the protection of endangered assets, cultural values and the environment. The operational response level, typically reactive, is clearly expressed in the Civil Protection emergency plans. These, with respect to risk framework, should incorporate the characterization of the risk reference framework, the chronology of past occurrences and the definition of the sensible and strategic infrastructures for the civil protection operations. For the Portuguese Municipal Emergency Plans, landslide susceptibility maps are overlaid with the map of the exposed elements, which allows the assessment of exposure to landslides, although the risk is not quantified.

Following the previous approach present in Guillard and Zêzere (2012) the main objectives of this work are: (i) to assess the landslide susceptibility at the municipal scale; (ii) to integrate landslide susceptibility maps on land use planning by setting National Ecological Reserve "Slope instability prone areas"; and (iii) to integrate landslide susceptibility maps on civil protection and emergency management actions accounting exposed elements. The study area is the Loures municipality $\left(168 \mathrm{~km}^{2}\right)$, located north of Lisbon in Portugal (Fig. 1).

\section{Data}

\section{Landslide Inventory}

In this work we consider only landslides of the slide type, following the classification of Cruden and Varnes (1996). Falls and flows were excluded from the municipal landslide inventory because they are residual in number and typically of small size in the study area.

The Loures municipality landslide inventory was based on (1) stereoscopic interpretation of aerial photographs obtained in 1982 and 1983 at the 1:15,000 scale, (2) interpretation of digital orthophotomaps (pixel $=0.5 \mathrm{~m}$ ) dated from 2004, and (3) detailed geomorphological field mapping made in the study area since 1980 with regular updates.

The landslide inventory contains 621 slides, including rotational slides (RS), shallow translational slides (STS) with slip surface depth $\leq 1.5 \mathrm{~m}$ and deep-seated translational slides (D-STS) with slip surface depth $>1.5 \mathrm{~m}$ (Fig. 1). The total affected area is approximately $1.5 \mathrm{~km}^{2}$, which represents $0.87 \%$ of the total study area and the landslide density is 3.7 landslides $/ \mathrm{km}^{2}$. The main morphometric characteristics and landslide typologies of the municipal landslide inventory are summarized in Table 1.

\section{Landslide Predisposing Factors}

A dataset of seven predisposing factors were used to assess landslide susceptibility for each type of landslide referred in Table 1: slope, aspect, plan slope curvature, slope over specific catchment area ratio, geology, soil type and land 


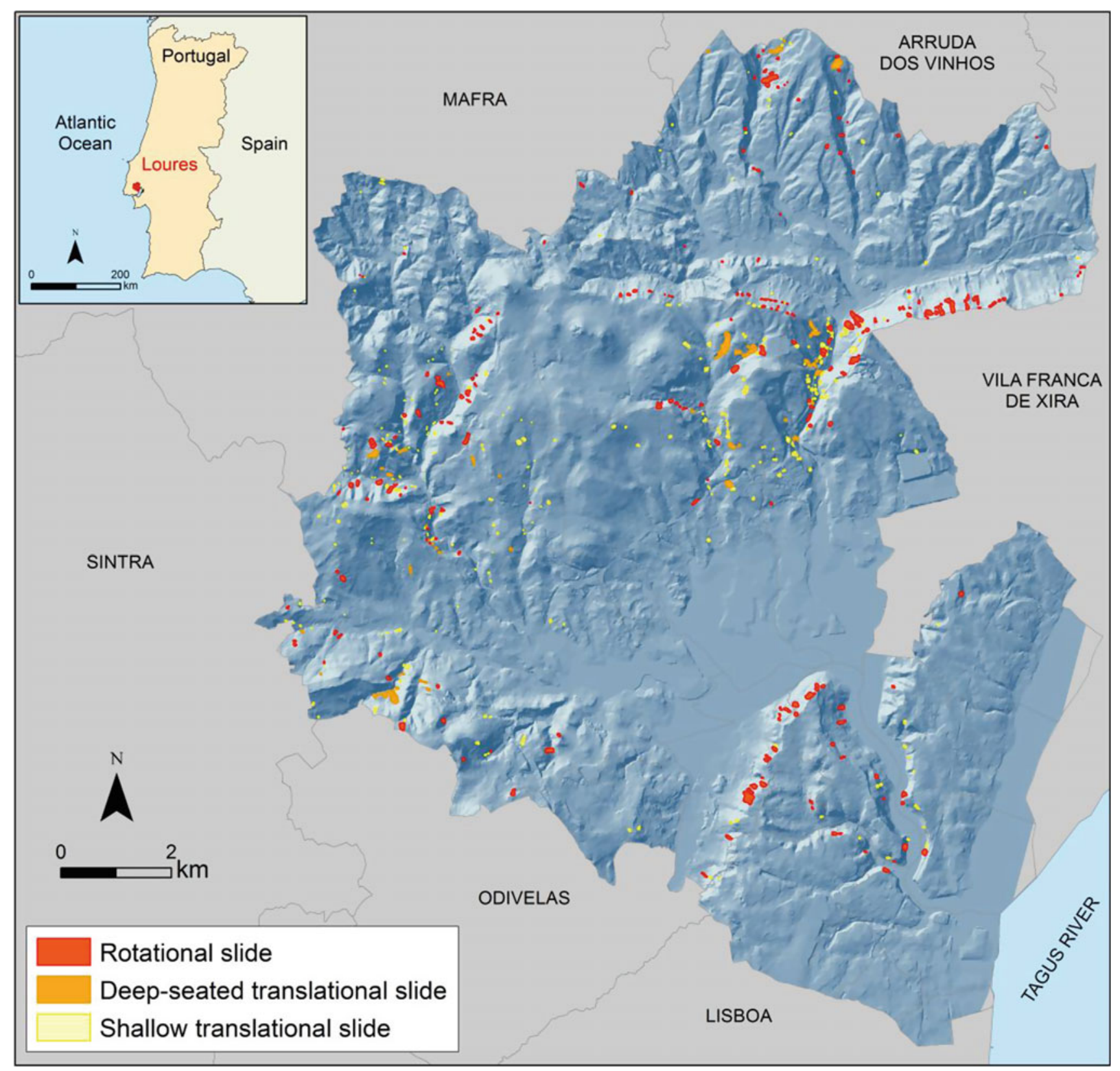

Fig. 1 Landslide inventory of Loures municipality and Loures municipality location (top-left figure)

Table 1 Main characteristics of the landslide inventory of the Loures municipality

\begin{tabular}{|l|l|l|l|l|} 
& \multicolumn{2}{l}{ Landslide type } & & \\
& RS & D-STS & STS & Total \\
\hline Number & 246 & 62 & 311 & 621 \\
\hline Min. area $\left(\mathrm{m}^{2}\right)$ & 193 & 237 & 65 & 65 \\
\hline Max. area $\left(\mathrm{m}^{2}\right)$ & 31,245 & 48,623 & 7899 & 48,623 \\
\hline Mean area $\left(\mathrm{m}^{2}\right)$ & 3278 & 5761 & 976 & 2366 \\
\hline Std. Dev. $\left(\mathrm{m}^{2}\right)$ & 3749 & 8109 & 1094 & 3897 \\
\hline Total area $(\mathrm{ha})$ & 80.6 & 35.7 & 30.3 & 147 \\
\hline Density $\left(\# / \mathrm{km}^{2}\right)$ & 1.5 & 0.4 & 1.8 & 3.7 \\
\hline Affected area $(\%)$ & 0.48 & 0.21 & 0.18 & 0.87 \\
\hline
\end{tabular}


use. Additional information on this dataset can be found in Guillard and Zêzere (2012).

\section{Exposed Elements}

The relevant exposed elements considered for the Loures municipality were identified and classified according to the Portuguese Methodological Guide for the production of municipal risk mapping and for the development of municipal-based Geographic Information Systems (Julião et al. 2009). Those include the urban and industrial structures and infrastructures (e.g. regular buildings, industrial areas) and the elements that are required for emergency response (e.g., hospital and health system; school system; fire department and facilities of other civil protection agents and civil and military authorities; road/railway/air transport infrastructures) and for basic support to population (e.g., main networks of water, electricity and fuel supply; telecommunications networks), which are considered Strategic, Vital and/or Sensitive Elements (SVSE).

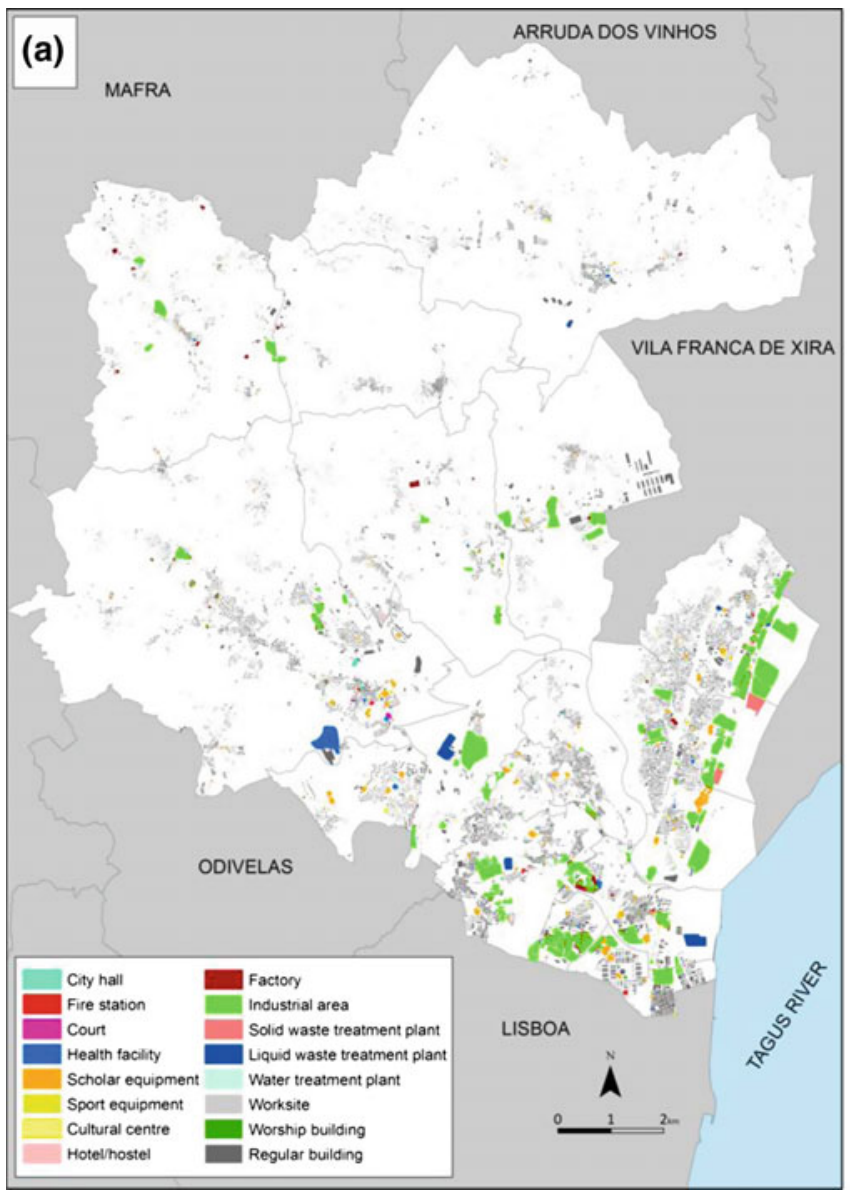

The Exposed Elements were disaggregated into 34 classes of SVSE that are shown in Fig. 2a, b.

\section{Methods}

\section{Landslide Susceptibility Assessment, Validation and Classification}

Three landslide type-based susceptibility models, one for each considered landslide type (RS, STS, D-STS), were produced using the statistical, bivariate, Information Value method (Yin and Yan 1988). Landslide susceptibility models were elaborated at a pixel-based grid of $5 \times 5 \mathrm{~m}$. As independent variables the data-set of seven predisposing factors were used. The dependent variable in each landslide type-based susceptibility model is the landslide inventory subset corresponding to a specific landslide type (Fig. 1).

To evaluate the predictive capacity of each landslide type-based susceptibility model, each model was crossed with the corresponding landslide group used for modelling

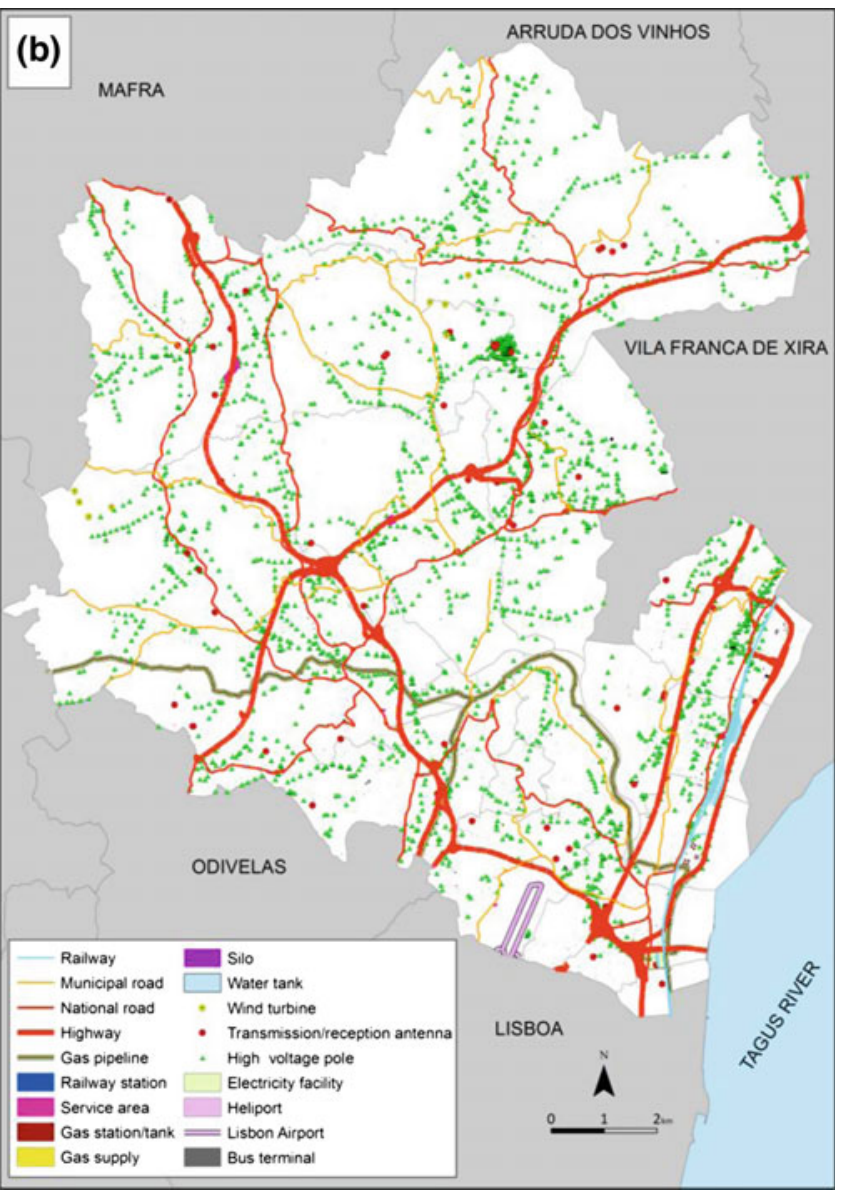

Fig. 2 Exposed elements of Loures municipality considered as Strategic, Vital and/or Sensitive Elements 
(model success). Validation results were graphically expressed by success-rate curves and the models global quality was quantified calculating the Area Under the Curve (AUC).

Each landslide type-based susceptibility map was classified in five classes: Very high, High, Moderate, Low and Very low. The upper limit of each class defined by the proportion of study area necessary to accommodate the following cumulative landslide area of the landslide validation group: 50; 70; 90; 95; and 100\%.

The final landslide susceptibility map was obtained by combining the three landslide type-based susceptibility maps produced at a first moment individually for each landslide type. The three landslide type-based susceptibility maps were overlapped and the final susceptibility value attributed to each pixel of $25 \mathrm{~m}^{2}$ within the study area was the highest susceptibility class found, considering the three landslide type-based susceptibility maps in that terrain unit.

\section{Integration of Landslide Susceptibility Maps in Land Use Planning}

The criteria for the integration of landslide areas and landslide prone areas in NER are defined for Portugal at the municipal level through a set of strategic guidelines. Accordingly, the following areas should be included in the NER: (i) scarps with slope over $100 \%$ and the protection buffers to the scarp upper limit and lower limit that should be at least equal, to the scarp height; (ii) the complete landslide inventory and a surrounding protection area of $10 \mathrm{~m}$ for each individual landslide; and (iii) the landslide susceptible area obtained with the Information Value statistical method that ensures the validation (inclusion) of a fraction not less than $70 \%$ of total area of the municipal landslide inventory.

\section{Integration of Landslide Susceptibility Maps in Civil Protection Emergency Planning}

The assessment of the exposure to landslides is one of the main objectives of the integration of spatial information related to landslide susceptibility to civil protection actions. To evaluate the exposure to landslides the 34 categories of SVSE were overlapped to the final landslide susceptibility map, and the exposed elements that fall into the Very high and High landslide susceptibility classes are considered to be potentially at risk.

\section{Results and Discussion}

\section{Landslide Susceptibility Assessment, Validation and Classification}

The classified landslide type-based susceptibility maps resulting from the application of the Information Value method to the set of seven independent predisposing factors and to each landslide modelling group (RS, STS and D-STS) are presented in Fig. 3a, b, c, respectively. The final landslide susceptibility map for the Loures municipality resulting from the integration of the above-mentioned landslide susceptibility maps is shown in Fig. 3d.

Table 2 summarizes the area corresponding to each landslide susceptibility class of the three landslide type-based susceptibility maps and of the final landslide susceptibility map. The areas classified as Very high and High susceptible to slide occurrence validate the $70 \%$ of landslide occurrences within the municipality and are the ones that should integrate the NER. Considering only landslide type-based susceptibility maps, these classes correspond to $11.2,10.3$, and $16.5 \%$ of the Loures territory, respectively. In all models the Low and Very low susceptibility classes are dominant ranging from 66 to $78.6 \%$ of the total area.

The final municipal landslide susceptibility map is similar to the landslide type-based susceptibility maps. In fact more than half of the municipality $(51.8 \%)$ is associated to Low or Very low landslide susceptibility (Table 2), not justifying special concerns, on the assumption that future interventions in the territory will not cause drastic changes in the current topography. The Moderate susceptibility class is larger in area (26\% of total area) when compared with the landslide type-based susceptibility maps. Interventions in these areas are possible, but should be avoided both, slope cuts and embankments not supported by an engineering geology project. The High and Very high susceptibility is observed in $22.1 \%$ of the territory. Due to its geomorphological and geotechnical characteristics, these areas are not suitable for building structures or infrastructures implementation.

The overall landslide susceptibility models fit, expressed by the corresponding success-rate curves obtained in the validation process are shown in Fig. 4.

The level of adjustment of each landslide type-based susceptibility model to the respective landslide inventory is also observed by the AUC values calculated for each success-rate curve. The landslide susceptibility model that presents the highest adjustment is the one constructed for the 
Fig. 3 Landslide susceptibility models of Loures municipality. a rotational slides; b deep-seated translational slides; $\mathbf{c}$ shallow translational slides; d Final landslide susceptibility map
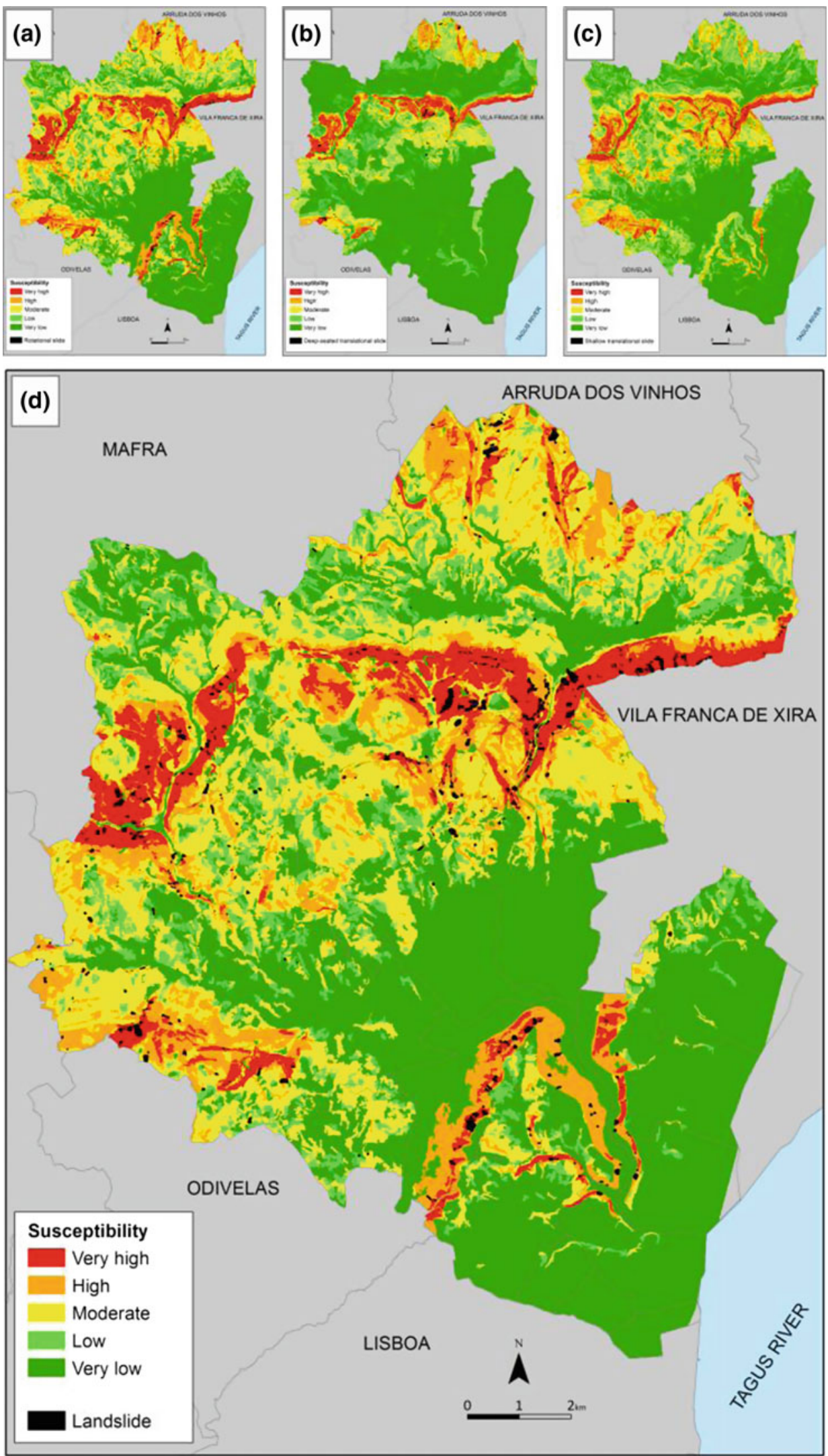
Table 2 Percentage of Loures municipality area in each class of each landslide susceptibility map

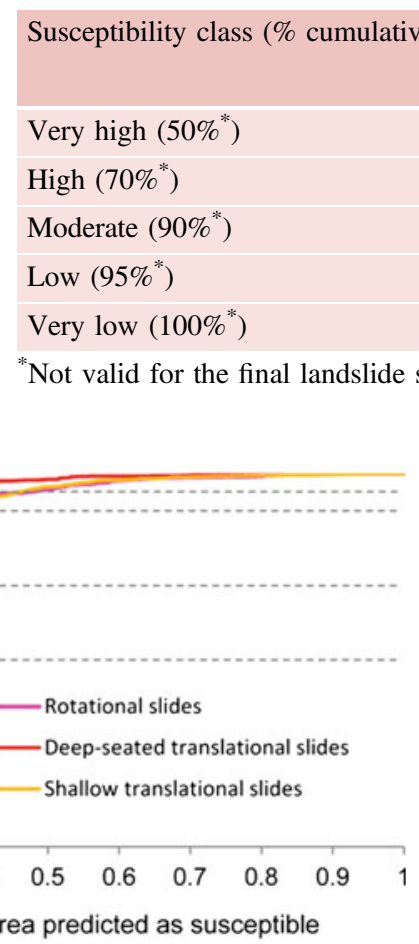

Fig. 4 Success-rate curves produced for each landslide type-based susceptibility model

Deep-seated translational slides $(\mathrm{AUC}=0.913)$. This model is followed by the models constructed for the rotational slides $(\mathrm{AUC}=0.889)$ and for the shallow translational slides $(\mathrm{AUC}=0.868)$.

The performance associated to each curve, for each class threshold of the landslide susceptibility maps can be inferred from Table 2. The deep-seated translational slides model has the best performance, expressed by the lowest percentage of the study area present in the highest susceptibility classes (Very high and High $=$ Validation of $70 \%$ of the landslide area constrained to only $10.3 \%$ of the study area) In the case of the final landslide susceptibility map, $97 \%$ of the total unstable area identified in the Loures municipality are included in the Very High and High susceptibility classes, which cover $22.1 \%$ of the study area.

\section{Integration of Landslide Susceptibility Maps in Land Use Planning}

The final NER map is shown in Fig. 5. This map includes: (i) the intersected area covered by the two highest landslide susceptibility classes that ensure the validation of $70 \%$ of each of the three considered landslide subsets (RS, STS and D-STS) corresponding to 3441.3 ha. This area constitutes the largest contribution from the perspective of landslides to NER; (ii) the landslides of the landslide inventory and an additional protection buffer zone of $10 \mathrm{~m}$ to each individual landslide (269.8 ha); and (iii) the scarps with slopes over $100 \%\left(45^{\circ}\right)(8.9 \mathrm{ha})$. As all scarps are included within the Very high or High landslide susceptibility classes, it was not necessary to define the protection buffers to the scarp upper limit and lower limit.

There is some overlapping between the three components of the NER and the final area covered by the NER in the study area is 3494 ha $(20.8 \%$ of the study area).

\section{Integration of Landslide Susceptibility Maps in Civil Protection Emergency Planning}

The spatial distribution of the 34 classes of exposed elements considered in the municipality of Loures, superimposed to the final landslide susceptibility map are showed in Figs. 6a, b. The potential risk associated to the exposed elements location results from the intersection of areas classified with Very high or High landslide susceptibility and the exposed elements distribution are shown in Fig. 2a, b. The elements that fall in these classes are more likely to be damaged in a non-specified time span due to the occurrence of landslides that are typically triggered in the study area by rainfall (intense rainfall episodes or long lasting rainfall periods) and eventually by earthquakes (Zêzere et al. 2015; Vaz and Zêzere 2015).

Tables 3 and 4 summarize the elements exposed to landslide hazard in the study area. It should be highlighted that 18 types of exposed elements never occur in High or Very high susceptibility classes, which let them in a more favorable condition with respect to landslide hazard. These types of exposed elements are: city hall; court; fire station; solid waste treatment plant; liquid waste treatment plant; water treatment plant; bus terminal; health facilities; sport equipment; cultural center; railway station; heliport; Lisbon airport; gas supply; factory; worksite; hotel/hostels; and railway.

Among the elements exposed to landslide hazard (i.e., located in areas classified with Very high or High susceptibility to landslide occurrence, it was possible to identify (Tables 3 and 4): 393 high voltage poles; 5 wind turbines; 5 


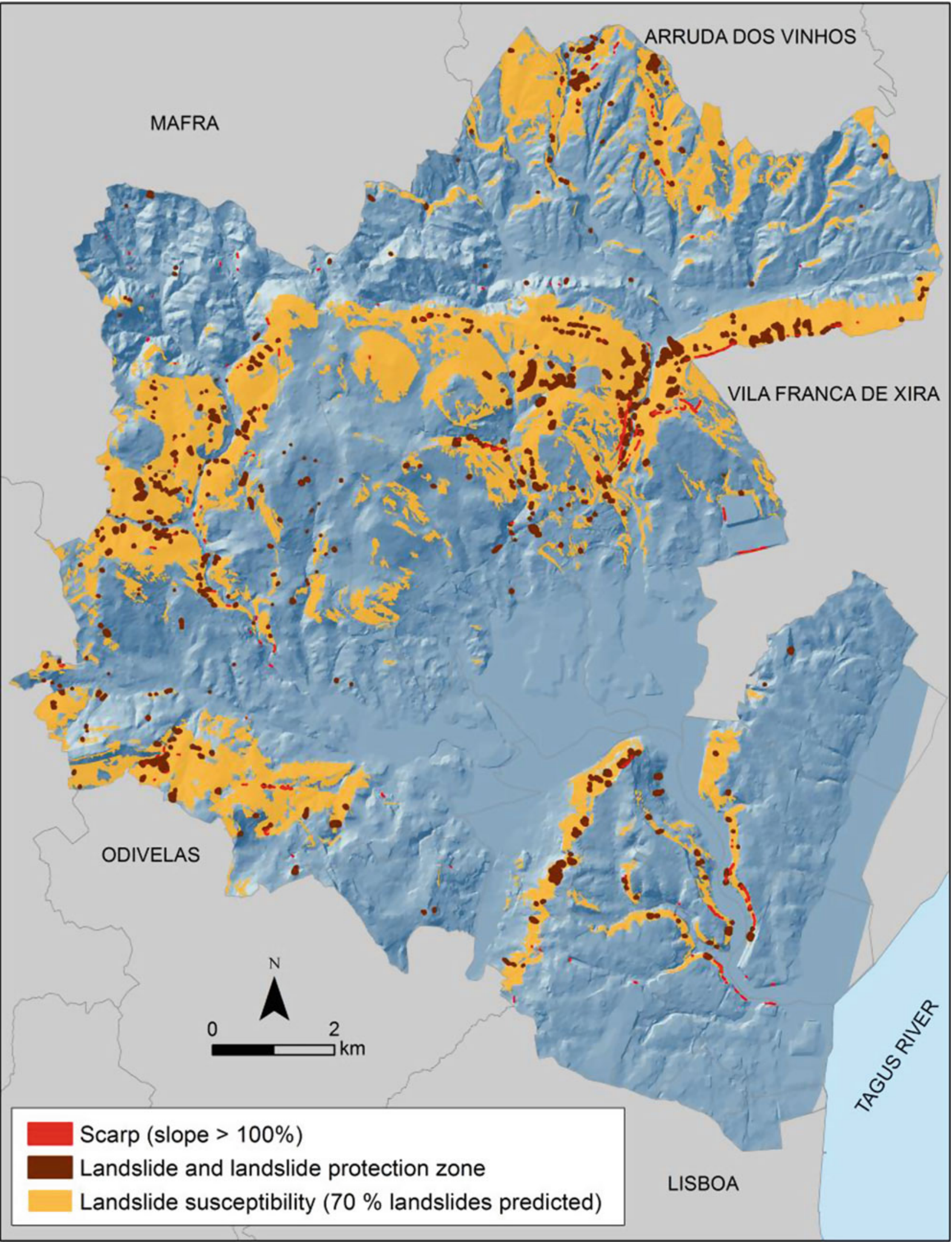

Fig. 5 Distribution of each landslide susceptibility component to the Loures municipal NER definition 

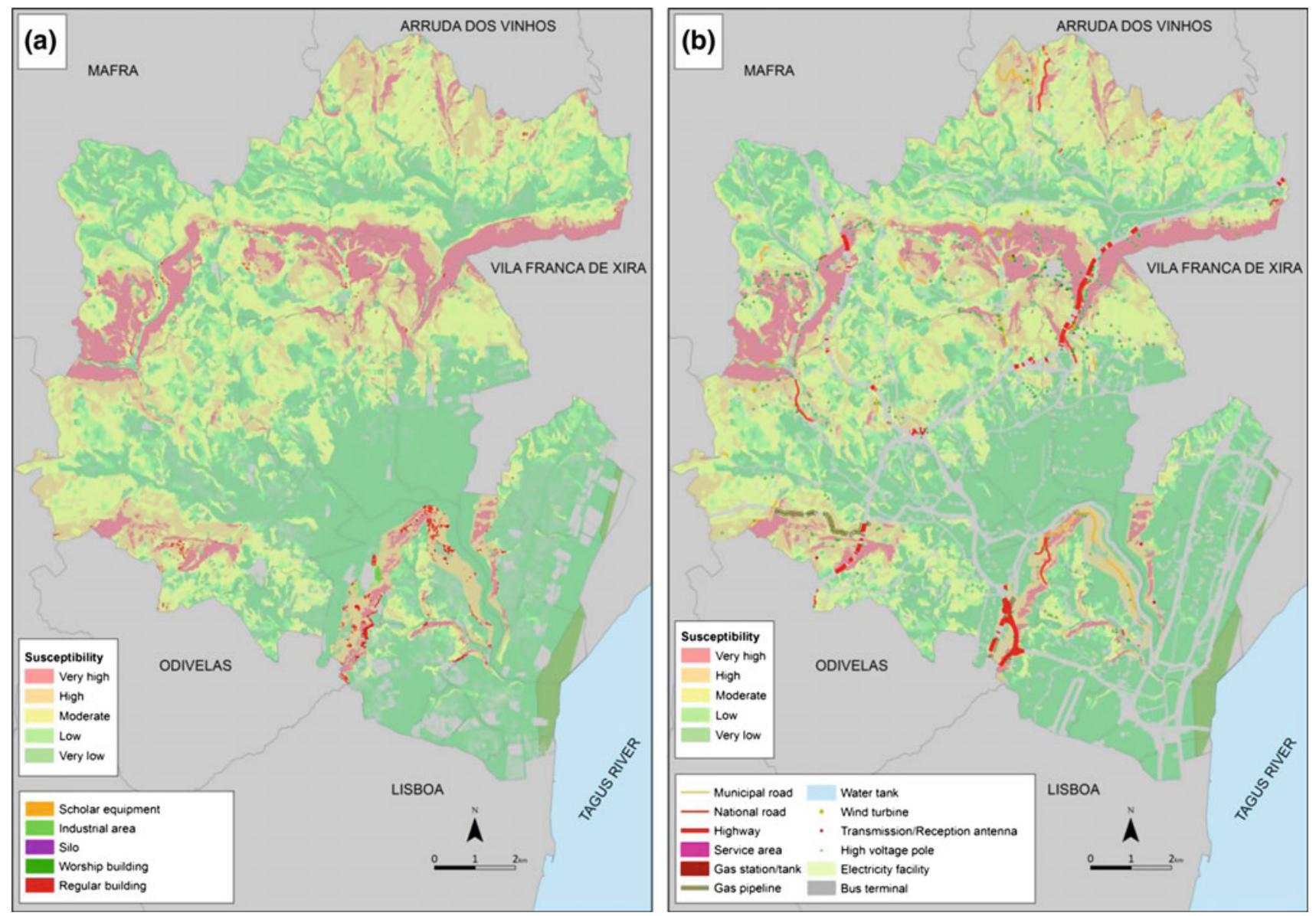

Fig. 6 Exposed elements overlay with the landslide susceptibility in Loures municipality

Table 3 Exposed elements (points and polygons) in Very high and High landslide susceptibility classes

\begin{tabular}{|l|r|l|l|}
\hline Exposed elements & Total \# buildings & $\begin{array}{l}\text { Buildings in very high and high } \\
\text { susceptibility classes }\end{array}$ \\
\hline City hall & & $(\#)$ & $(\%)$ \\
\hline Court & 2 & 0 & 0 \\
\hline Fire station & 2 & 0 & 0 \\
\hline Solid waste treatment plant & 9 & 0 & 0 \\
\hline Liquid waste treatment plant & 2 & 0 & 0 \\
\hline Water treatment plant & 7 & 0 & 0 \\
\hline Bus terminal & 4 & 0 & 0 \\
\hline Health facility & 3 & 0 & 0 \\
\hline Scholar equipment & 29 & 0 & 0 \\
\hline Sport equipment & 244 & 2 & 0.8 \\
\hline Cultural Centre & 66 & 0 & 0 \\
\hline Worship building & 1 & 0 & 0 \\
\hline Railway station & 117 & 3 & 2.6 \\
\hline Heliport & 8 & 0 & 0 \\
\hline
\end{tabular}


Table 3 (continued)

\begin{tabular}{|l|r|r|l|}
\hline Exposed elements & Total \# buildings & $\begin{array}{l}\text { Buildings in very high and high } \\
\text { susceptibility classes }\end{array}$ & $(\%)$ \\
\hline Lisbon Airport & & $(\#)$ & 0 \\
\hline Transmission/Reception antenna & 1 & 0 & 8.5 \\
\hline Wind turbine & 59 & 5 & 62.5 \\
\hline High voltage pole & 8 & 5 & 14.6 \\
\hline Electricity facility & 2696 & 393 & 6.4 \\
\hline Gas supply & 440 & 28 & 0 \\
\hline Gas station/tank & 2 & 0 & 1.9 \\
\hline Service area & 54 & 1 & 2.0 \\
\hline Industrial area & 51 & 1 & 5.3 \\
\hline Factory & 150 & 8 & 0 \\
\hline Water tank & 1327 & 0 & 9.2 \\
\hline Worksite & 422 & 39 & 0 \\
\hline Silo & 46 & 0 & 2.0 \\
\hline Hotel/hostel & 51 & 1 & 0 \\
\hline Regular building & 92,813 & 4689 & 5.1 \\
\hline & & & \\
\hline
\end{tabular}

Table 4 Exposed elements (linear) in Very high and High landslide susceptibility classes

\begin{tabular}{|l|l|l|l|}
\hline Exposed elements & Total $(\mathrm{km})$ & $\begin{array}{l}\text { Extension in very high and high } \\
\text { susceptibility classes }\end{array}$ \\
\hline Highway & & $(\mathrm{km})$ & $(\%)$ \\
\hline National road & 88.8 & 9.7 & 10.9 \\
\hline Municipal road & 89.6 & 9.7 & 10.9 \\
\hline Railway & 69.2 & 11.8 & 17.1 \\
\hline Gas pipeline & 32.9 & 0 & 0 \\
\hline
\end{tabular}

transmission/reception antennas; 8 industrial areas; 39 water tanks; 1 silo; 1 gas station/tank; 1 service area; 2 buildings of educational institutions; 3 worship buildings; 28 buildings with electricity facilities; 4689 regular buildings; $3.5 \mathrm{~km}$ of gas pipeline; $9.7 \mathrm{~km}$ of motorways; $9.7 \mathrm{~km}$ of national roads; and $11.8 \mathrm{~km}$ of municipal roads.

\section{Conclusions}

Landslide susceptibility was evaluated considering each landslide typology and further combined in order to produce a final landslide susceptibility map, more conservative, for the entire municipality territory. This final landslide susceptibility map allows evaluate that in Loures municipality, 1347 ha are associated to a Very high landslide susceptibility, and 2372 ha to High landslide susceptibility, which corresponds both to $22.1 \%$ of the entire municipal territory. These areas do not present geomorphological and geotechnical suitability for building structures or infrastructures and are integrated into the National Ecological Reserve.

From the civil protection and emergency management point of views the elements at risk located in the Very high or High landslide susceptibility classes were identified and may suffer damage resulting from the occurrence of landslides. Among these: critical power, water, gas distribution and storage facilities, industrial areas, national road networks, industrial areas and 2 buildings of educational institutions.

The final landslide susceptibility map of the Loures municipality is now included in the new version of the Municipal Master Plan. In addition, the map combining 
the landslide susceptibility with the Exposed elements is being used by the Municipal Civil Protection Service that cross this information with the Population Census data in order to estimate people exposed to landslides in the study area.

Acknowledgements This work was supported by the project FORLAND - Hydrogeomorphologic risk in Portugal: driving forces and application for land use planning [PTDC/ATPGEO/1660/2014] funded by the Portuguese Foundation for Science and Technology (FCT). S.C. Oliveira and S. Pereira are Post-Doc fellows of the Portuguese Foundation for Science and Technology (FCT) [grant number SFRH/BPD/85827/2012 and SFRH/BPD/69002/2010], respectively.

\section{References}

Cruden DM, Varnes DJ (1996) Landslide types and processes. In Turner AK, Schuster RL (eds) Landslides investigation and mitigation. Transportation Research Board. National Academic Press, Washington DC Special Report 247, pp 36-75
Guillard C, Zêzere JL (2012) Landslide susceptibility assessment and validation in the framework of municipal planning in Portugal: The case of Loures Municipality. Environ Manage 50(4):721-735. doi:10.1007/s00267-012-9921-7

Julião RP, Nery F, Ribeiro JL, Branco MC, Zêzere JL (2009) Guia metodológico para a produção de cartografia municipal de risco e para a criação de sistemas de informação geográfica (SIG) de base municipal. Autoridade Nacional de Protecção Civil, Direcção-Geral do Ordenamento do Território e Desenvolvimento Urbano, Instituto Geográfico Português

Vaz T, Zêzere JL (2015) Landslides and other geomorphologic and hydrologic effects induced by earthquakes in Portugal. Nat Hazards. doi:10.1007/s11069-015-2071-5

Yin K, Yan T (1988) Statistical prediction models for slope instability of metamorphosed rocks. In: Bonnard C (ed) Landslides. Proceedings of the fifth international symposium on landslides, Balkema, Rotterdam, pp 1269-1272

Zêzere JL, Vaz T, Pereira S, Oliveira SC, Marques R, Garcia RAC (2015) Rainfall thresholds for landslide activity in Portugal: a state of the art. Environ Earth Sci 73(6):2917-2936. doi:10.1007/s12665014-3672-0
Open Access This chapter is licensed under the terms of the Creative Commons Attribution 4.0 International License (http:// creativecommons.org/licenses/by/4.0/), which permits use, sharing, adaptation, distribution and reproduction in any medium or format, as long as you give appropriate credit to the original author(s) and the source, provide a link to the Creative Commons license and indicate if changes were made.
The images or other third party material in this chapter are included in the chapter's Creative Commons license, unless indicated otherwise in a credit line to the material. If material is not included in the chapter's Creative Commons license and your intended use is not permitted by statutory regulation or exceeds the permitted use, you will need to obtain permission directly from the copyright holder. 